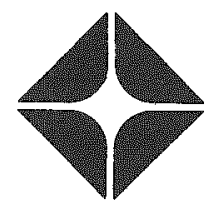

\title{
WORK PLAN FOR REMOVAL OF DIVISION OF MILITARY APPLICATION EQUIPMENT \\ 234-5 Z BUILDING
}

H. E. Johnson

Apri1 26, 1974

PREPARED FOR THE U.S. ENERGY RESEARCH AND DEVELOPMENT ADMINISTRATION UNDER CONTRACT E (45-1) 2130

\section{PRELIMINARY REPORT}

THIS REPORT CONTAINS INFORMATION OF A PRELIMINARY NATURE. IT IS SUBJECT TO REVISION OR CORRECTION AND THEREFORE DOES NOT REPRESENT A FINAL REPORT. IT WAS PREPARED PRIMARILY FOR INTERNAL USE WITHIN THE ATLANTIC RICHFIELD HANFORD COMPANY. ANY * EXPRESSED VIEWS AND OPINIONS ARE THOSE OF THE AUTHOR AND NOT NECESSARILY OF THE COMPANY.

\section{NOTICE}

THIS REPORT WAS PREPARED AS AN ACCOUNT OF WORK SPONSORED BY THE UNITED STATES COVERNMENT. NEITHER THE UNITED STATES NOR THE UNITED STATES ENERGY RESEARCH AND DEVELOPMENT ADMINISTRATION, NOR ANY OF THEIR EMPLOYEES. NOR ANY OF THEIR CONTRACTORS, SUBCONTRACTORS OR THEIR EMPLOYEES, MAKES ANY WARRANTY, EXPRESS OR IMPLIED, OR ASSUMES ANY LEGAL LIAEILITY OR RESPONSIEILITY FOR THE ACCURACY, COMPLETENESS OR USEFULNESS OR ANY INFORMATION, APPARATUS, PRODUCT OR PROCESS DISCLOSED, OR REPRESENTS THAT ITS USE WOULD NOT IMFRINGE MR IVATELY OWNED RIGHS. 


\section{DISCLAIMER}

This report was prepared as an account of work sponsored by an agency of the United States Government. Neither the United States Government nor any agency Thereof, nor any of their employees, makes any warranty, express or implied, or assumes any legal liability or responsibility for the accuracy, completeness, or usefulness of any information, apparatus, product, or process disclosed, or represents that its use would not infringe privately owned rights. Reference herein to any specific commercial product, process, or service by trade name, trademark, manufacturer, or otherwise does not necessarily constitute or imply its endorsement, recommendation, or favoring by the United States Government or any agency thereof. The views and opinions of authors expressed herein do not necessarily state or reflect those of the United States Government or any agency thereof. 


\section{DISCLAIMER}

Portions of this document may be illegible in electronic image products. Images are produced from the best available original document. 
WORK PLAN FOR REMOVAL OF DIVISION OF MILITARY APPLICATION EQUIPMENT

$234-5$ Z BUILDING

\author{
H. E. Johnson
}

Plant Engineering Section

Operations Technical Support Department

\author{
Apri1 26, 1974
}

The subject work plan has been reviewed and is approved for adoption of the expense work item entitled, "Removal of Division of Military Equipment 234-5 Z Building."

Approved by:
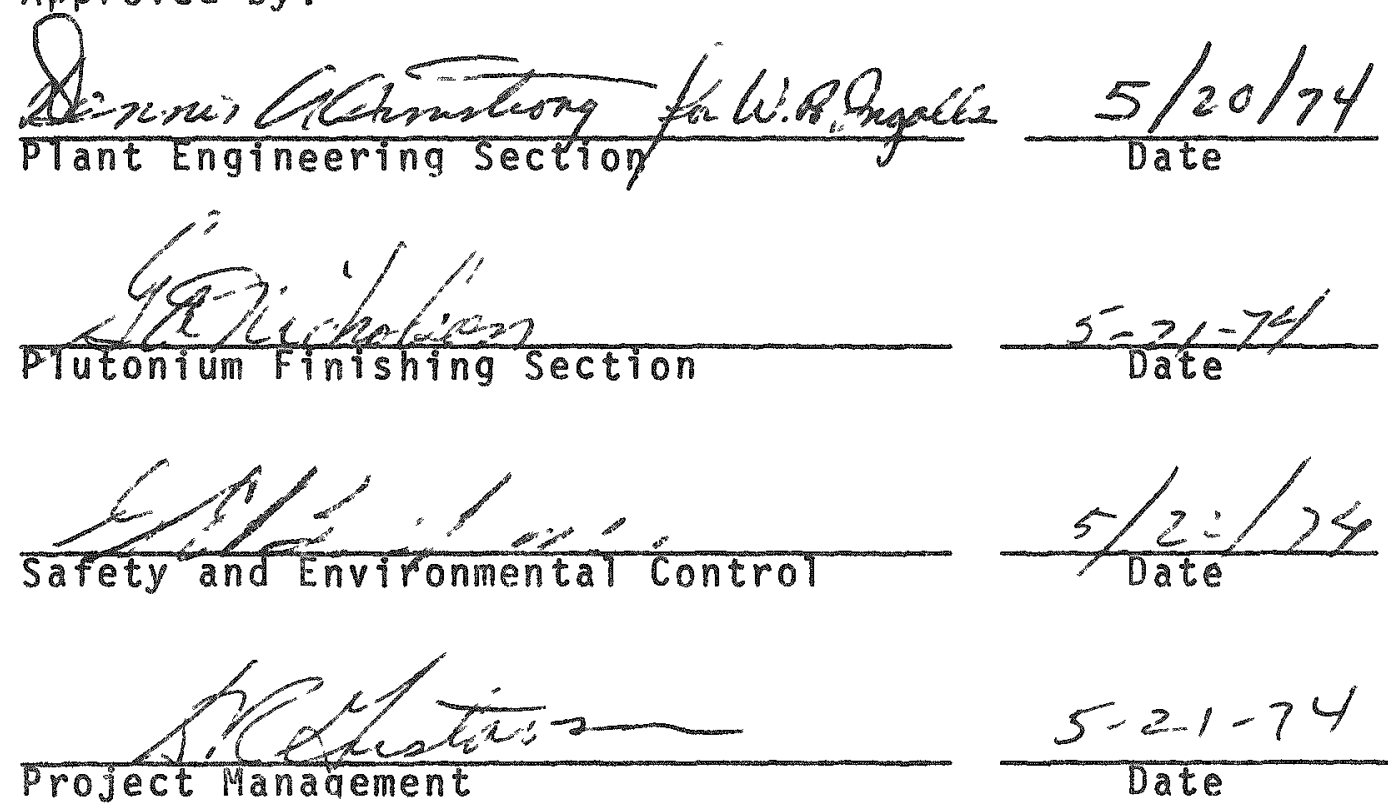

$\frac{5-21-74}{\text { Date }}$ 


\author{
WORK PLAII FOR REMOVAL OF \\ DIVISION OF MILITARY APPLICATIOH EQUIPMENT \\ $234-5$ Z BUILDING \\ H. E. Joirnson \\ Plant Engineering Section \\ Operations Technical Support Department \\ operations Division
}

Apri1 26, 1974

Operated for the Atomic Energy Commission by Atlantic Richfield Hanford Company under Contract AT (45-1)-2137 
TABLE OF CONTENTS

Page

OBJECTIVE

BACKGROUND 3

WORK TASK RESPONSIBILITIES 3

CRITERIA 4

WORK TASKS
EOUIPMENT AND SHORING DESIGN

EQUIPMENT AND SHORING DESIGN
ROUTE PREPARATION

GLOVE BOX PREPARATION 9

TRAISPORTATION AND PACKAGING 11

MOVE THE BURIAL BOX TO THE BURIAL TREHCH

AND BURY THE ASSEMBLY 11

CLEAIUP AND REMOVE COLD EQUIPMENT
SPECIAL NOTATION

PRODUCTION INTERFEREHCES 12

REFERENCES 12

$\begin{array}{ll}\text { APPENDICES } & 14\end{array}$ 
WORK PLAN FOR REMOVAL OF

\section{DIVISION OF MILITARY APPLICATION EQUIPIENT \\ 234-5 Z BUILDING}

\section{OBJECTIVE}

This documents presents the work plan for accomplishing the removal and burial of fabrication equipment [Division of Military Application (DMA) equipment] in the 234-5 Z Buildinq.

\section{BACKGROUND}

The DMA equipment located in the 234-5 2 Building was used for the fabrication of plutonium weapon components from 1949 to 1965. Since 1965, the equipment with certain exceptions has remained in layaway status although tied into building services for contamination control and safety.

\section{WORK TASK RESPONSIBILITIES}

The Atlantic Richfield Hanford Company (ARHCO) wi1l:

- Have overall management of and final responsibility for the program.

- Assume those responsibilities assigned to it in ARH-3n32 (unclassified). April 29, 1974, J.D. Anderson, "Specifications and Standards for the Burial of Richland Operations Solid Wastes, "includina the surveyina of the solid radioactive waste containers as specified in paragraph 4.1 .4 of ARH-3032 and detailed in reference 2 . Portable equipment furnished by ARHCO will be used. 
- Provide design criteria for any major items to be designed by Vitro Engineering Uivision of Automation Industries, Inc. (Vitro)

- Maintain records for property accounting.

Vitro Engineering will be responsible to:

- Provide design drawings of burial boxes, miscellaneous blanking plates, and shoring.

- Check the impact on building services of severing the DMA equipment from the building services (primarily ventilation).

- Maintain sufficient records of changes to the building to allow modification of existing drawings and other pertinent records to reflect the final configuration.

The J. A. Jones Construction Company will be responsible for the physical removal of glave boxes. construction of equipment as requested, transporting and unloading of the burial boxes, and all cleanup work.

\section{CRITERIA}

The following criteria snall be satisfied in performance of this work:

- The standards and specifications, including records and accounting for packaging and subsequent burial are to be in accordance with AEC Manual Chapter 0511.

- Burial boxes will be either of steel construction in accordance with ARH-2239 (unclassified), March 15, 1972, R. A. Kennedy. "Design Criteria - Transuranic Dry Waste Burial Containers," or FRP covered plywood as recommended in $\mathrm{ARH}-3061$.

- Hydraulic fluid in equipment to be buried will be drained, packaged and buried in separate containers (see reference 2 ). 
- Loose combustibles, such as glove box gloves and glove box debris will be scparated and packaged in 55-gallon drums of an approved type. Exposed ports will be covered with suitable covers.

- The prinary boundary of contamination containment will be the glove box walls.

- Plastic film necessary for contamination control will be packaged as separate combustibles where practical. otherwise, the plastic will be left on the glove boxes and packaged with the glove boxes.

- Room areas will be left in a contamination-free state.

- Service piping and duct work will be sealed off (blanked) as close to the ceiling or remaining equipment as possibie.

- Electrical services to the equipment will be deactivated.

- Noncontaminated equipment (if unconditionally released by radiation monitoring) can be salvared if desired.

- Glove box packagina into the burial boxes may be performed out of the building to allow maximum use of cranes, but only if in the judgment of supervision, the weather shall be dry, no rain, and the wind velocity shall be less than 15 miles per hour.

- Glove boxes will not be stored outside. Glove boxes will either be stored within the building (and tied to the building $E-4$ system if required for contalination controll) or placed into a burial box and sealed.

- Contamination level standaras will be those of $A R H-3 n 32$.

- Lead. lead glass and other external appurtenances may be removed from the qlove boxes and buried in accordance with ARH-3732 or salvaged provided if criteria above are satisfied. 


\section{WURK TASKS}

\section{EQUIPMENT AND SHORING DESIGN}

Burial box design will satisfy the general criteria and the following additional criteria:

- The number of sizes and shapes of burial boxes will be minimized.

- The burial boxes will contain an intact qlove box with associated plumbing and duct work where possible and feasible.

- Consideration will be given to lifting requirements.

- Consideration will be given to choosina sizes and shapes to allow the most efficient use of the burial trench when stacking the boxes.

- The burial boxes will have structural capacity to withstand stacking (where possible) and earth loading.

Blanking plates and gaskets will be designed to cover openings in conveyors, openings in glove boxes created by the removal of ducts, filters and glove ports.

Flooring and ceiling supports will be analyzed to determine the extent of shoring required to support floors during transportation of glove boxes and to support the ceiling when a wall is removed to supply a passageway for the glove boxes.

ROUTE PREPARATION

Prepare route for glove box removal. Five routes will be used (see Appendix B).

\section{"A" Route}

The route for removal of the "A" fabrication line will be through door 651, out corridor $13 \mathrm{~A}$ and outside through the north door between columins 19 and 20 .

\section{Requirements}

- Install shoring under floor where the route crosses corridor 13. 
- Place floor protection along corridor $13 \mathrm{~A}$.

- Remove the electrical cabinetry supporting HA-3I and eliminate or salvage per the criteria.

- Supply packaging equipment outside of 234-5 2 Building.

- Erect a door across $13 A$ (between rows $A$ and $B$ ) to provide an air lock.

Special Problems

- Hone additionar to "A" Route above is expected.

"B" Route

The route for removal of the inspection line glove boxes will be out of the north door between columns 19 and 20 via corridor $13 \mathrm{~A}$.

Requirements

- Remove part of the wall between corridor $13 \mathrm{~A}$ and the inspection room.

- Removal of building wall north of HI-74 C\&.L may be required. This vill impose a ventilation problem.

Special problems

- Water service lines for fire protection may have to be rerouted to allow full height availability of the corridor.

"Cisoute

A route for removal of the west end of the "c" fabrication line would be through the wall along row $E$ at column 20. west along corridor 7 and out of the building. An air lock exists created by the doors between columns 21 and 22 .

The apparent alternate route past glove box $H C-46 \mathrm{~F}$ and out along route $D$ (below) is not considered as it would be hampered by the need to provide floor shoring over a pit between rows $D$ and $E$ and column 22 (reference $H-2-16131$ ) and the shallow pipe chase between columns 22 and 23. 


\section{Requirements}

- Provide floor shoring in the underneath tunnel for corridor 7 from the wall penetration at column 2 ? to outside of the building.

- Provide floor protection along that portion of corridor 7 used for this passage.

- Hove packaging equipment from outside of corridor $13 \mathrm{~A}$ to outside (west of) corridor 7.

- Provide a passageway through the wall between columns 20 and 21 and row $E$.

- The concrete pads presently supporting the machining glove boxes ( $H C-41$ through $H C-43$ ) will have to be removed to allow passage of the more distant glove boxes through the wall penetration.

- The floor beneath the path for the removal of the machining glove boxes should be checked for structural capability.

Special Problems

- Water service lines for fire protection may have to be rerouted to allow full height utilization of corridor 7.

"D" Route

The route for removal of glove box $\mathrm{HC}-43 \mathrm{~V}$ will be out the door at column 24 via corridor $239 \mathrm{~A}$.

Requirements

- No special preparation is needed.

\section{Special Problems}

- None is anticipated.

\section{"E" Route}

The route for removal of the east end of the "C" fabrication line will be via the south door between columns 12 and 13 via corridor 6 and 7 out through room 170 . Note that this route need only be used for the large pieces of equipment which would minimize disturbance with normal traffic through room 170. 


\section{Requirements}

- Install shoring under corridor 5 and 7 flooring as required.

- Provide floor protection as required.

- Make passageways through the walls as required.

- Move the packaging equipment from the west side of the building to the area outside of room 170 .

Special Problems

- The packaging equipment must be coordinated to have no impact on normal shipping through this area (loading dock).

- Water service lines for fire protection may have to be rerouted to allow full height availability of corridor 6 and 7 .

\section{GLOVE BOX PREPARATION}

\section{General Requirements}

- If supervision deems it necessary, connect a portable E-4 line to the glove box that will maintain a vacuum, one-half to one-inch of water, in the glove box.

- Isolate the glove box from the adjoining glove box and seal off both exposed ports with gasketed blanking plates.

- Disconnect the ducting and seal the ends with blanking plates. Make each piece a primary barrier to contamination.

- Disconnect the services as indicated in "criteria." If the lines penetrate the glove box, drain the lines and package the fluids in 55-galion drums as combustibles as indicated in ARH-3032 and reference 2 . Package plumbing for removal from the building with the glove box.

- Refrigerant equipment and lines will probably be free of contamination but this must be verified. This equipment can be removed but need not be buried (if verified as clean). 
- Hydraulic equipment distant from, but sunporting, the glove box must be drained, and the fluid handled as instructed in $A R H-3032$ and detailed in reference 2 .

Special Problems

"A" Fabrication Line Glove Boxes and Equipment

- None is anticipated.

"C" Fabrication Line Glove Boxes (West End) and Equipment, Except HC-48V

- The glove boxes containing lathes must be removed from

the concrete pads upon which the glove boxes rest

(M1 and M2 series above).

- Storage glove box HC-45 may be split horizontaliy and sealed with metal blanking plates to allow removal.

Inspection Line Glove Boxes

- The conveyor lines to the surrounding glove boxes do not (generaliy) have joints coinciding with the glove box flanges. The conveyor lines thus will have to be cut to provide convenient packages.

- Glove box HI-74 S\&L are two separate glove boxes located one above the other. Separating these would allow removal out through corridor 13 A.

"C" Fabrication Line Glove Boxes and Equipment (East End)

- Glove box HC-22S may have to be separated similar to HC- 45 S (west end).

- Glove box HC-19-A and. B will have to be subdivided into smaller packages to allow removal.

- Glove box HC-20 does not appear to be capable of subdividing into smaller packages. Some investigation must be made to determine if attitude alteration will allow passage through to the outside of the building.

- Giove box HC-24BX presents the same problem as HC-20. Glove box HC-24BX can be separated but whether this will lower the overall profile adequately must be determined. 
Glove Box $H C-48 \mathrm{~V}$

- ilo problem is anticipated.

IRAISPORTATION AND PACKAGIIG

Each glove box will be removed from the E-4 ventilation system, placed in its burial box, sealed, and transported to the burial ground without undue delay. If an overnight delay (or longer) is anticipated, retain the glove box inside the building and sealed off until the above sequences can be continuous.

Special Problems

- HI-68X may require removal of the door labyrinth to allow passage out of room 192A wherein the glove boxes are located.

- HI-74 S\&L may have to be removed north through the building wall.

MOVE THE BURIAL BOX TO THE BURIAL TRENCH AND BURY THE ASSEMBLY

The procedure and required records used to accomplish this burial are documented in the references under "criteria." Several burial boxes will require special permission because the burial boxes are larger than the units allowed. The machining glove boxes will require special handing equipment at the burial trench because of weight. No handling equipment of that capacity is available at the trenches.

\section{CLEAIUP AIND REMOVE COLD EQUIPRENT}

A decision will be made by ARHCO regarding the disposition of the electrical consoles and switch boxes associated with the to be removed glove boxes and the shielding walls associated with glove box HI-74 SíL. The shielding walls surrounding glove boxes $H C-45$ and $H C-22 S$ should be moved to room 221 .

All the areas formerly occupied by the removed glove boxes will be decontaminated, surveyed and rendered contamination free.

Contaminated flooring should be removed by cutting away the plastic floor covering (if existant) and chipping away the 
concrete beneath to a maximum depth of two inches (if removal of the floor covering ias not eliminated the contamination). Restore the concrete and flooring with new materials to be in harmony with the old flooring. Al1 contaminated material will be packaged in 55-gailon drums and elininated in accordance with ARH-3032.

\section{SPECIAL NOTATION}

The entire area should be painted in accordance with building requirements.

ilote that the philisophy of removal has been to contain contamination within existing boundaries. Thus, contamination cleanup should be minimal.

The walls will be replaced where special passageways were formed, using plasterboard construction. lloles formed by the removal of conveyors will be walled in, usinc, plasterboard construction except between rooms $192 \mathrm{~A}$ and $192 \mathrm{~B}$ and between $192 \mathrm{~A}$ and 1920 where holes will be filled with concrete. All shoring under the floors will be removed.

The conveyor within room $192 \mathrm{~B}$ shall be removed first and the hole blanked as defined above.

\section{PRODUCTION IIITERFERENCES}

Ho production interferences are anticipated. By removing most of the equipment through the north door at corridor $13 \mathrm{~A}$. interference with passage along corridor 6 and 7 is minimized. The remaining equipment that must be moved across this busy corridor can be scheduled.

\section{REFEREICES}

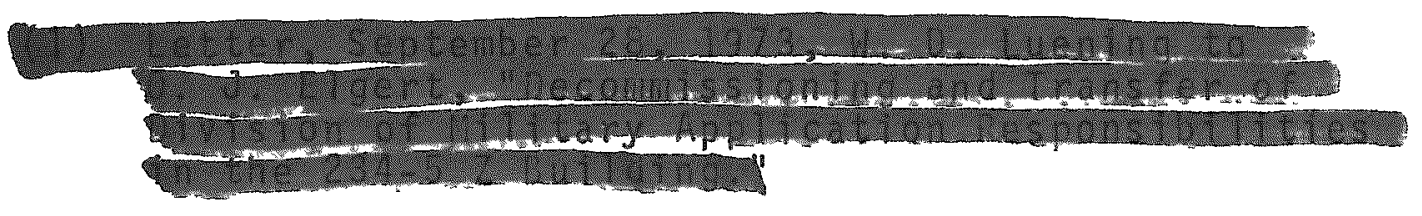




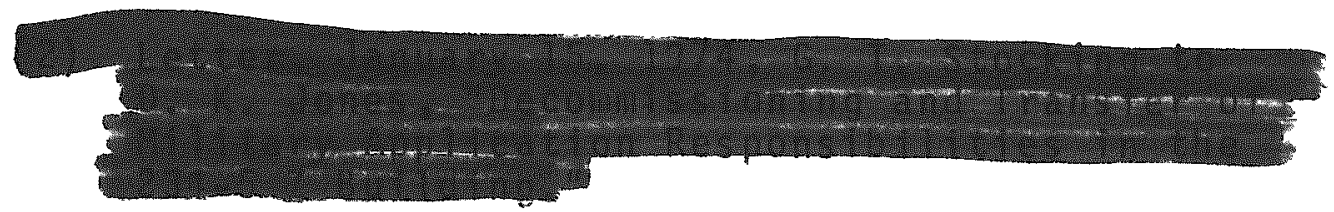

The following drawings are also pertinent to this document.

1. H-2-25030, March 29, 1966, M. E. Borgeson, "234-5 Z Building Key Dwg [sic], List."

2. SK-2-2869, "Z Plant Floor Plan." 
APPENDIX A

SUMMARY OF REMOVAL OF THE MAJOR PIECES OF DMA EQUIPMENT

Sequence of Removal

"A" Line

$H A-31 T T$

$H A=30$

$H A-29 B P$

$H A-27 F T$

$H A-26 D B$
Route

$A$
$A$
$A$
$A$

Hydraulic Units

$H A-29 \# 1$

HA-29 \#2

$\mathrm{HA}=27$

$H A=31$ (two items)

"C" Line - West End

$\mathrm{HC}-42 \mathrm{MI}$

$H C-43 \quad M I$

$\mathrm{HC}-42 \mathrm{M} 2$

$\mathrm{HC}-43 \mathrm{M2}$

HC-42 Conveyor and M 3

HC-42 MI Hyd. Unit

HC-42 M2 Hyd. Unit

$\left.\begin{array}{ll}H C-43 & E \\ H C-43 & M X\end{array}\right)$ on balcony

HC -43 C

HC-43 MI Hyd. Unit

HC-43 M2 Hyd. Unit

$\mathrm{HC}-41 \mathrm{C}$ and $\mathrm{M} 3$

Hyd. Unit Mi

HC-41 MI

HC. $41 E$

$H C-42 E$

MC- 41 MX

$H C-42 M X$

$H C-44 C$ and $M 3$

$H C-40$ DB

$H C-45 S$

Inspection Line

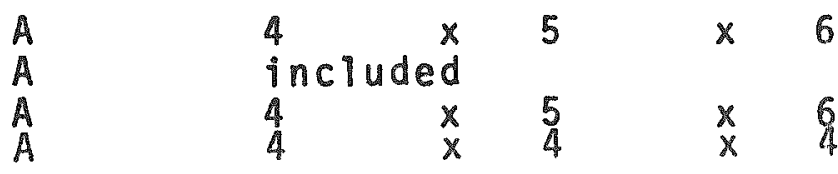

$c$
$c$
$c$
$c$
$c$
$c$
$c$
$c$
$c$

$\begin{array}{rrrrrrrr}4 & 1 / 2 & x & 9 & 1 / 2 & x & 6 & 1 / 2 \\ 4 & 1 / 2 & x & 9 & 1 / 2 & x & 6 & 1 / 2 \\ 4 & 1 / 2 & x & 9 & 1 / 2 & x & 6 & 1 / 2 \\ 4 & 1 / 2 & x & 9 & 1 / 2 & x & 6 & 1 / 2 \\ 4 & 1 / 2 & x & 16 & & x & 7 & \\ 4 & 1 / 2 & x & 4 & 1 / 2 & x & 4 & \\ 4 & 1 / 2 & x & 4 & 1 / 2 & x & 4 & \\ 4 & 1 / 2 & x & 6 & & x & 6 & \\ 4 & 1 / 2 & x & 4 & & x & 6 & \\ 4 & 1 / 2 & x & 16 & & x & 7 & \\ 4 & 1 / 2 & x & 4 & 1 / 2 & x & 4 & \\ 4 & 1 / 2 & x & 4 & 1 / 2 & x & 4 & \\ 4 & 1 / 2 & x & 16 & & x & 7 & \\ 3 & 112 & x & 5 & & x & 6 & \\ 4 & 1 / 2 & x & 9 & 1 / 2 & x & 6 & 1 / 2 \\ 4 & 1 / 2 & x & 6 & & x & 5 & \\ 4 & 1 / 2 & x & 6 & & x & 6 & \\ 4 & 1 / 2 & x & 4 & & x & 6 & \\ 4 & 1 / 2 & x & 4 & & x & 6 & \\ 4 & 1 / 2 & x & 16 & & x & 7 & \\ 6 & & x & 15 & & x & 10 & \\ 17 & & x & 5 & & x & 7 & \end{array}$

size

Length Width Height


Sequence of Relloval

III -63

$1,2,3,4$

$5,6,7$

HI-52 Conveyor

$1,2,3,4$

$5,6,7,8$

HI-5I Conveyor

$1,2,3,4$

$5,6,7,8$

accessories

HI-53 Conveyor

$1,2,3,4$

$5,6,7,8$

Inspection Accessories

"C" Line - East End
Route Length Height

B

B

B

B

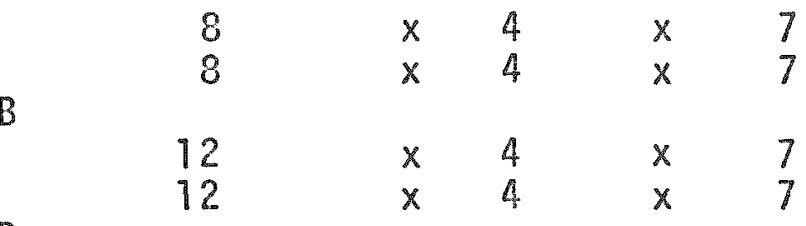

$\begin{array}{rrrrr}12 & x & 4 & x & 7 \\ 16 & x & 4 & x & 7 \\ 4 & x & 5 & x & \varepsilon\end{array}$

$\begin{array}{rrrrrr}B & 10 & x & 4 & x & 7 \\ & 8 & x & 4 & x & 7 \\ B & 14 & x & 4 & x & F\end{array}$

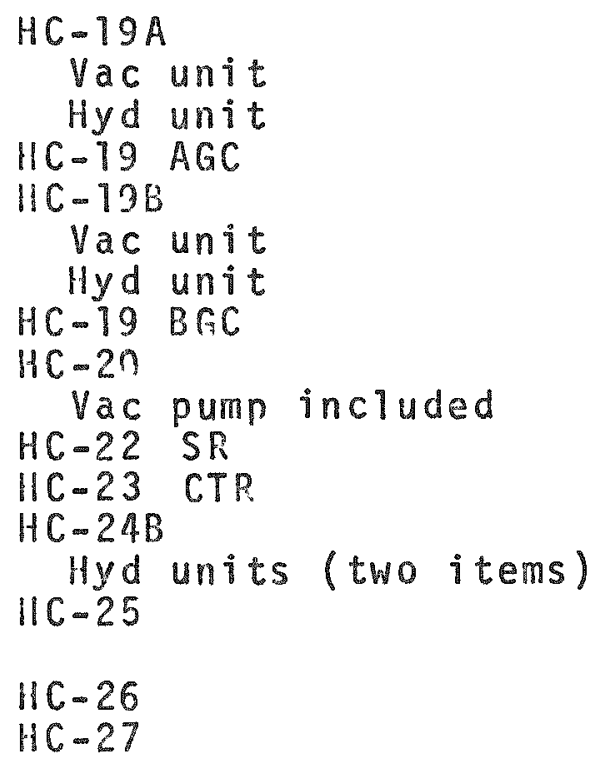

\begin{tabular}{|c|c|c|c|c|c|c|c|}
\hline E & & 16 & $x$ & 5 & & $x$ & 8 \\
\hline E & & 10 & $x$ & 4 & & $\mathrm{x}$ & 3 \\
\hline & & \multicolumn{6}{|c|}{ included } \\
\hline E & & $71 / 2$ & $x$ & 5 & & $x$ & $41 / 2$ \\
\hline E & & 16 & $x$ & 5 & & $x$ & $\varepsilon$ \\
\hline & & \multirow{2}{*}{\multicolumn{6}{|c|}{ incruded $x$}} \\
\hline & & & & & & & \\
\hline \multirow{2}{*}{ [ } & & 17 & $x$ & 4 & & $x$ & 3 \\
\hline & & 7 & $x$ & 7 & \multirow[t]{2}{*}{$1 / 2$} & $x$ & 12 \\
\hline & & 17 & $x$ & 5 & & $x$ & 7 \\
\hline or & C & 16 & $x$ & 6 & & $x$ & $61 / 2$ \\
\hline & & 14 & $x$ & 8 & & $x$ & 6 \\
\hline or & C & 5 & $x$ & 3 & & $x$ & 3 \\
\hline or & C & 6 & $x$ & 6 & & $x$ & 6 \\
\hline & & & $x$ & 3 & & $x$ & 6 \\
\hline or & c & $61 / 2$ & $x$ & 3 & $1 / 2$ & $x$ & 6 \\
\hline & & $81 / 2$ & & & & & \\
\hline
\end{tabular}

Miscellaneous

$H C-48$ VC

Non-combustibles

Combustibles
D $61 / 2 \times 4 \times 6$ Any 20 drums Any 2 drums

This listing is not all inclusive. Minor pieces of support equipment that would require continued surveillance if not removed, should be removed if on the first and balcony floors. Duct level equipment is intended to be retained unless specially otherwise designated. 
$2+2 H z-1$

jEDJHEHA APPENDIX B

$\frac{1}{2} \frac{1}{2}$

I.1. In

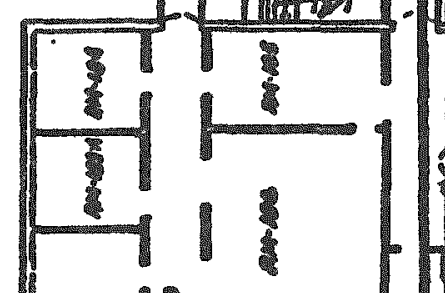
19. 1 .

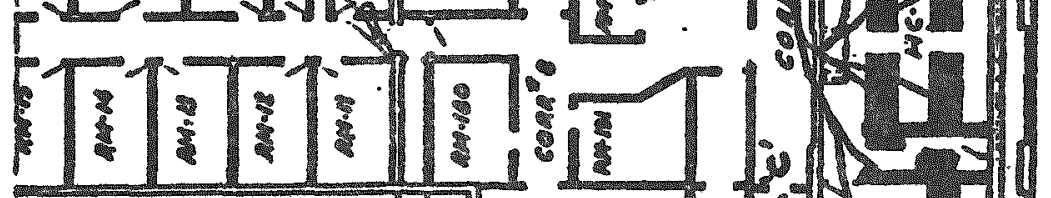

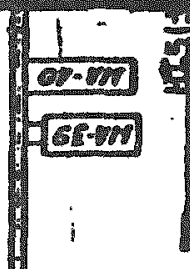

1

5ment

t)

?

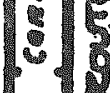

inth

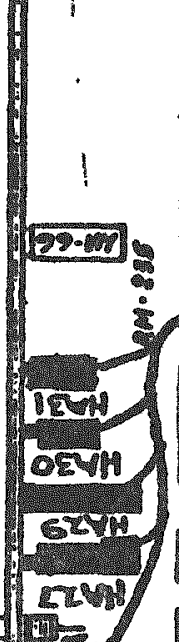

II

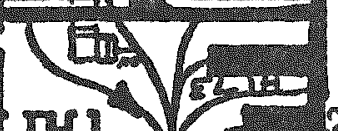

(9)

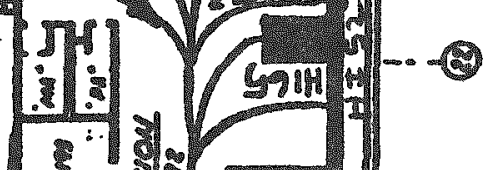

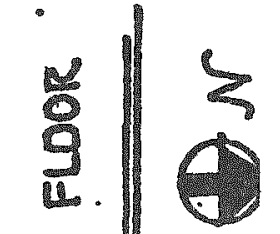

$-6$
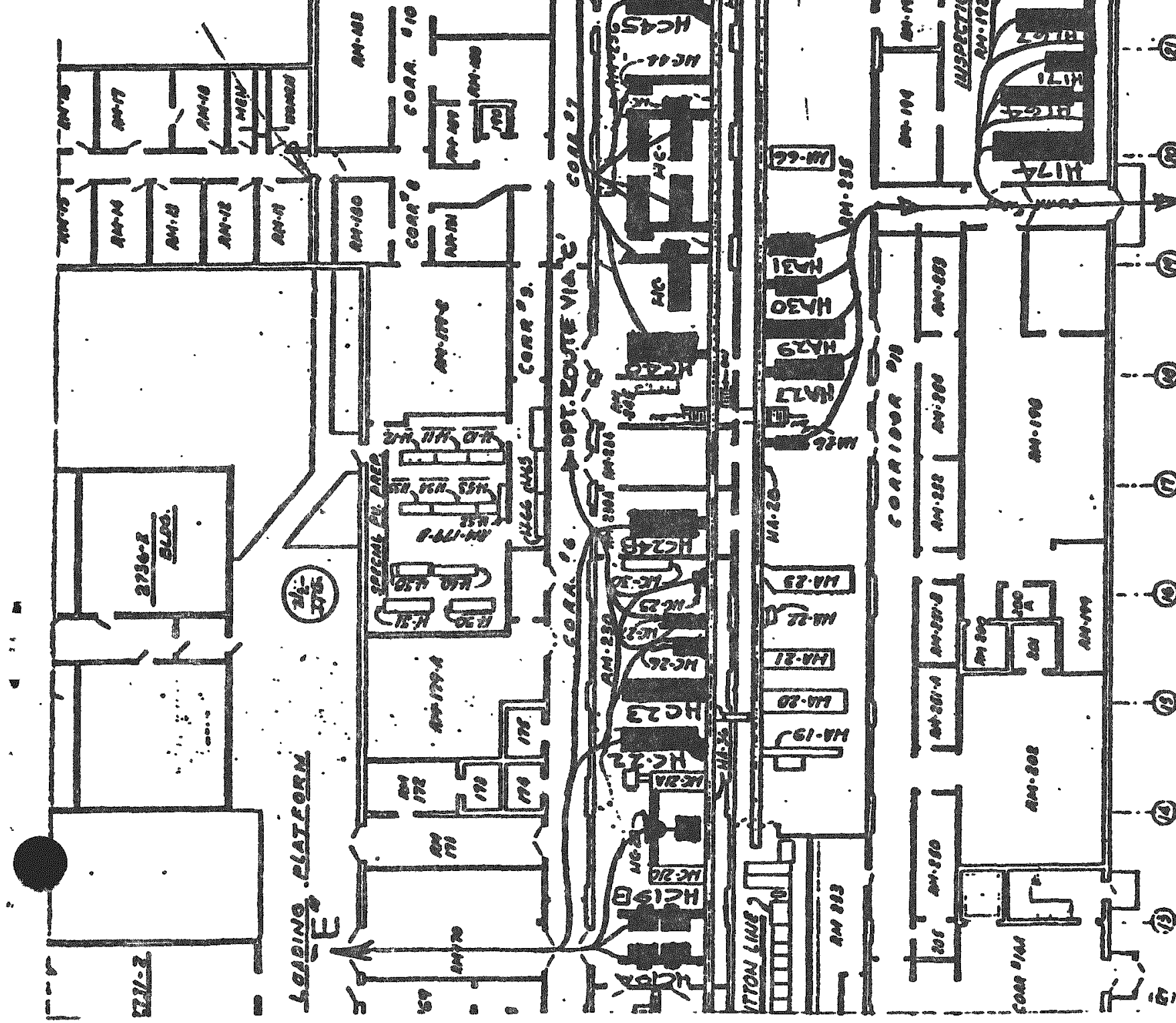

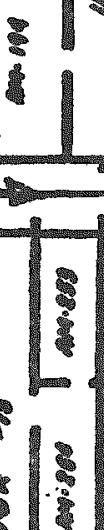

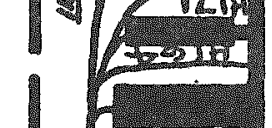

$-\operatorname{lin}^{-0}$

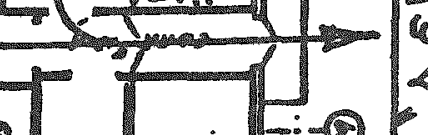

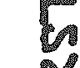

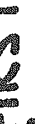

(1) 42

81

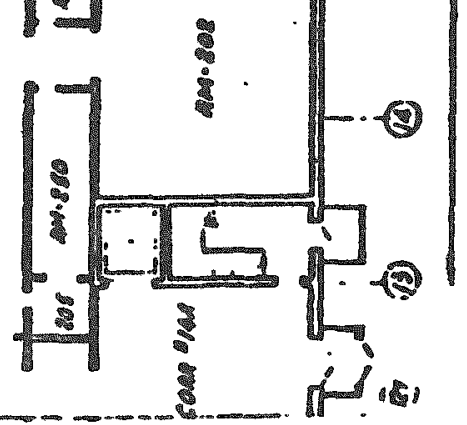

